SINAI Journal of Applied Sciences

\title{
In vitro ENHANCEMENT OF SOME CANOLA (Brassica napus, L.) GROWTH CHARACTERISTICS USING PLANT GROWTH REGULATORS
}

\author{
Ahmed S. Attaya* \\ Dept. Plant Prod., Fac. Environ. Agric. Sci., Suez Canal Univ., Egypt.
}

\begin{abstract}
This study was designed to investigate the effect of some factors affecting on in vitro growth enhancement of Topas canola genotype. During establishment stage, MS medium strengths (full and half), explant types (shoot tip and axillary node) and cytokinin types (BA and Kin) were investigated. Using shoot tip explants on full MS medium that supplemented with $1.0 \mathrm{mgl}^{-1} \mathrm{BA}$ proved to be the best treatment during this stage. In addition, different BA concentrations $\left(0.0,0.1,0.5\right.$ and $\left.2.5 \mathrm{mgl}^{-1}\right)$ and the same previous concentrations of IBA or NAA in the presence of $1.0 \mathrm{mgl}^{-1}$ of BA or Kin were examined during multiplication stage. Results indicated that BA proved to be the best cytokinin especially at $2.5 \mathrm{mgl}^{-1}$ or at $1.0 \mathrm{mgl}^{-}$ ${ }^{1}$ in the presence of $0.5 \mathrm{mgl}^{-1}$ IBA since it produced the maximum number of shoots/explant. During rooting stage, effects of auxin type (IBA and NAA) at different concentrations ( 0.0 , $0.1,0.5$ and $2.5 \mathrm{mgl}^{-1}$ ) and the same previous concentrations of IAA, NAA and 2,4-D in the presence of $0.5 \mathrm{mgl}^{-1}$ IBA were evaluated. Generally, using of half MS medium supplemented with $2.5 \mathrm{mgl}^{-1}$ IBA individual or $0.5 \mathrm{mgl}^{-1}$ IBA in combination with $0.1 \mathrm{mgl}^{-1}$ IAA stated to be the most suitable treatments for root induction and growth. Obtained plantlets were successfully acclimatized (70-80\% survivability) in peat moss and sand (1:1, v/v) medium in the greenhouse.
\end{abstract}

Keywords: Brassica napus, Shoot induction and multiplication, Plant growth regulators (PGRs), Murashige and Skoog medium (MS), in vitro root formation.

\section{INTRODUCTION}

Canola (Brassica napus L.) is belonging to the family Brassicaceae and ranks the second largest oilseed crop after soybean in global oil production (Ghnaya et al., 2008; Maheshwari et al., 2011; Borjian and Arak, 2013). Its oil is among the best types of edible oils used in human feeding especially in Northern Europe, United States, Canada, and China. Its high importance regarding to the lowest saturated fat content compared to all edible oils that contains $6 \%$ of saturated fatty acids and $94 \%$ non-saturated fatty acids and very low level of low density lipids (Cholesterol) and also contains Omega compounds that beneficial to human health (Al-Naggar et al., 2008). It is a widely and globally used for cooking, salad oil, and making margarine. Canola has a bright future to contribute in reducing oil deficiency gap between production and consumption of edible oil (El-Howeity and Asfour, 2012). Canola is grown in Egypt as a winter crop and one of the agricultural opportunities to increase canola production is expanding it into the new reclaimed regions because it competes with clover and wheat in old Delta. Thus, growing canola in salt-affected soils or in less-fertile soils may become successful if it could produce a relatively high economic yield with low level of

\footnotetext{
* Corresponding Author: +201021289944

E-mail: ahmd.attaya@gmail.com
} 
inputs of nitrogen fertilizer (Moghaieb et al., 2006 ; Al-Naggar et al., 2008).

In recent years, a great deal of effort has gone into improving the quality of Brassica napus using classical breeding, several tissue culture and genetic engineering techniques. It is among the first crops to be genetically modified and transformed for improving its production and quality at very significant levels in commercial production. Cardoza and Stewart (2004) reported that various canola cultivars have been developed over the time, but only those that respond to in vitro regeneration can be used for biotechnological improvement. For that, various types of explants such as cotyledons (Cheng et al., 2005; Huang 2006; Bennett et al., 2008; Maheshwari et al., 2011), petioles, hypocotyls, leaves (He et al., 2006; Ghnaya et al., 2008; Liu et al., 2008; Maheshwari et al., 2011), stem cuttings, root cuttings, shoot buds (Eapen and Georg, 1997), and pollen grains or microspores (Shi et al., 2007; Cao et al., 2010) have been used for in vitro culture.

Regarding the influence of plant growth regulators on canola shoot induction and multiplication, Zihang and Bhalla (2004) reported that BAP was the most effective stimulator for shoot regeneration and 2.47 shoots per cotyledon explants were obtained with the combination of BAP (3.0 $\left.\mathrm{mgl}^{-1}\right)$, NAA $\left(0.2 \mathrm{mgl}^{-1}\right)$, and $\mathrm{GA}_{3}$ $\left(0.1 \mathrm{mgl}^{-1}\right)$. Chamandoosti et al. (2006) stated that callus after approximately one month of culture have been shooted with $2.0 \mathrm{mgl}^{-1}$ BA which produced $89 \%$ shoot induction.

Moreover, Moghaieb et al. (2006) used different concentrations of BA $(0.0,2.25$, 4.50, 7.25 and $9.0 \mathrm{mgl}^{-1}$ ) and they indicated that adventitious shoots emerged from the embryonic callus in the presence of $4.5 \mathrm{mgl}^{-1}$ BA. Ghnaya et al. (2008) evaluated four combinations of BA and NAA $\left(1.0 \mathrm{mgl}^{-1}\right.$ $\mathrm{BA}+0.1 \mathrm{mgl}^{-1} \mathrm{NAA}, 2.0 \mathrm{mgl}^{-1} \mathrm{BA}+0.2$ $\mathrm{mgl}^{-1} \mathrm{NAA}, 3.0 \mathrm{mgl}^{-1} \mathrm{BA}+0.3 \mathrm{mgl}^{-1} \mathrm{NAA}$ and $\left.4.0 \mathrm{mgl}^{-1} \mathrm{BA}+0.4 \mathrm{mgl}^{-1} \mathrm{NAA}\right)$. The best rate of plant regeneration was obtained with the combination of $3.0 \mathrm{mgl}^{-1} \mathrm{BA}$ with $0.3 \mathrm{mgl}^{-1} \mathrm{NAA}$ for all genotypes. Burbulis et al. (2010) noted that the combination of $4.0 \mathrm{mg}^{-1} \mathrm{BA}$ with $0.5 \mathrm{mgl}^{-1} \mathrm{NAA}$ was significantly improved shoot formation frequency.

In addition, Hussain et al. (2014) stated that medium with $5.0 \mathrm{mgl}^{-1}$ BAP with 0.5 $\mathrm{mgl}^{-1}$ IAA was used for shoot regeneration. Furthermore, the effect of plant growth regulators on canola root formation was reported by Zihang and Bhalla (2004) who evaluated three combinations of PGRs $(0.5$ $\left.\mathrm{mgl}^{-1} \mathrm{BA}+0.1 \mathrm{mgl}^{-1} \mathrm{NAA}\right),\left(0.5 \mathrm{mgl}^{-1} \mathrm{BA}+\right.$ $\left.0.2 \mathrm{mgl}^{-1} \mathrm{NAA}\right)$ and $\left(1.0 \mathrm{mgl}^{-1} \mathrm{BA}+0.1\right.$ $\left.\mathrm{mgl}^{-1} \mathrm{NAA}\right)$ and they noticed that the highest number of roots with tallest roots (9.51 and $4.7 \mathrm{~cm}$, respectively) were observed with the last combination. Also, Chamandoosti et al. (2006) were studied five treatments (control, $1.0 \mathrm{mgl}^{-1} \mathrm{NAA}, 2.0$ $\mathrm{mgl}^{-1} \mathrm{NAA}, 1.0 \mathrm{mgl}^{-1}$ IBA and $2.0 \mathrm{mgl}^{-1}$ IBA) and they found that $1.0 \mathrm{mg}^{-1}$ IBA was observed the highest frequency of shoots with rooting percentage (90\%). Burbulis et al. (2010) reported that proliferated shoots were rooted with 0.1 $\mathrm{mgl}^{-1}$ NAA.

However, Ismail (2012) tested different concentration of IBA $(0,0.1,0.2,0.3,0.4$, or $0.5 \mathrm{mgl}^{-1}$ ) and found that $0.3 \mathrm{mgl}^{-1}$ IBA gave the highest percentage $(62.9 \%$ and $45 \%$ for Bactol and Sarow-4, respectively), followed by 0.4 IBA $(51.8 \%$ and $30 \%$, for Bactol and Sarow-4, respectively. Hussain et al. (2014) cleared that the combination of $0.125 \mathrm{mgl}^{-1} \mathrm{IAA}+0.250 \mathrm{mgl}^{-1}$ IBA was the best for canola root formation.

The aim of the present study was to enhance some growth characteristics and morphogenesis of Topas canola genotype using plant growth regulators under aseptic conditions as a first key of biotechnological improvement for improving its production and quality. 


\section{MATERIALS AND METHODS}

\section{Plant Material and Explant Sterilization}

Seeds of canola genotype (Topas) were obtained from Agricultural Research Division, National Research Center, Egypt.

At plant tissue culture lab., Faculty of Environmental Agricultural Sciences, Suez Canal University and during the period from 2014 to 2015, The seeds were submerged in tap water with a few drops of detergent soap in a flask and shacked well for 10 minutes then rinsed under running tap water to remove the soap. Under aseptic condition in laminar air-flow hood, seeds were surface-sterilized with $70 \%(\mathrm{v} / \mathrm{v})$ ethanol for 2 minutes and subsequently surface sterilized by $20 \%$ Clorox (with $5 \%$ sodium hypochlorite) for $20 \mathrm{~min}$. explants were thoroughly rinsed three times with sterile distilled water after each previous step.

\section{Culture Medium and Conditions}

The sterile seeds (10 seeds per jar) were cultured on MS basal salt mixtures including vitamins (Murashige and Skoog, 1962) in jars containing $50 \mathrm{ml}$ medium, supplemented with $3 \%(\mathrm{w} / \mathrm{v})$ sucrose, $0.8 \%$ $(\mathrm{w} / \mathrm{v})$ agar and $0.1 \mathrm{gl}^{-1}$ myo-inositol. Medium $\mathrm{pH}$ was adjusted to $5.6-5.8$ before gelling and then autoclaved at $121^{\circ} \mathrm{C}$ for 20 min. after that the cultures were put in the dark for 7 days and they were maintained in an air conditioned incubation room at $22 \pm$ $2^{\circ} \mathrm{C}$ under $16 \mathrm{~h} /$ day photoperiod which provided by cool white fluorescent lamps (light intensity 2500 Lux.).

\section{Shoot Bud Induction and Proliferation}

After 3 weeks of seed germination, the in vitro shoot tip and axillary node explants $(0.5-1.0 \mathrm{~cm}$ length) were prepared from seedlings and cultured (4 explants/jar) on (full and half) MS medium supplemented with $3 \%(\mathrm{w} / \mathrm{v})$ sucrose, $0.8 \%(\mathrm{w} / \mathrm{v})$ agar and $0.1 \mathrm{gl}^{-1}$ myo-inositol in the presence of 0.5 $\mathrm{mgl}^{-1}$ of 6-Benzyladenine (BA) cytokinin. After 4 weeks from culture, the induced shoot buds were transferred to MS medium supplemented with $3 \%(\mathrm{w} / \mathrm{v})$ sucrose, $0.8 \%$ $(\mathrm{w} / \mathrm{v})$ agar and $0.1 \mathrm{gl}^{-1}$ myo-inositol in the presence of different concentrations (0.1, 0.5 and $2.5 \mathrm{mgl}^{-1}$ ) and combinations of BA, Kinetin (Kin), indole butyric acid (IBA) and $\alpha$-Naphthalene acetic acid (NAA) for shoot proliferation. Shoot induction percentage, number of shoots/explant, shoot length, number of leaves/shoot and callus formation percentage were the studied characteristics during this stage.

\section{In vitro Rooting}

The proliferated shoots $(0.5-1.0 \mathrm{~cm}$ length) of Topas genotype were used as explants and were cultured firstly on free MS medium for a week then were transferred to half strength MS medium. The medium was supplemented with $3 \%$ $(\mathrm{w} / \mathrm{v})$ sucrose and $0.8 \%(\mathrm{w} / \mathrm{v})$ agar in the presence of different concentrations $(0.1$, 0.5 and $2.5 \mathrm{mgL}^{-1}$ ) of auxins like (IBA and NAA), individual or $0.5 \mathrm{mgL}^{-1}$ IBA in combination with the previous concentrations of Indole acetic acid (IAA), NAA and 2,4Dichlorophenoxyacetic acid (2,4-D) for 4 weeks to monitor the initiation and quality of adventitious roots on the regenerated shoots. The cultures were maintained under cool white fluorescent lamps provided by Philips.

\section{Acclimatization of Plantlets}

The well-developed healthy in vitro rooted plantlets after 4 weeks were washed thoroughly under tap water and hardened for ex vitro. The plantlets were planted in pots containing a mixture of peat moss and sand in the ratio of $1: 1(\mathrm{v} / \mathrm{v})$ then placed in a plastic tunnel and wetted with tap water and covered with transparent plastic bags to maintain humidity. After 3 weeks, the established plants were transplanted to polyethylene bags containing garden soil and farmyard manure for further growth. The survival rate of in vitro propagated plantlets after 6 weeks of transplanting was $70-80 \%$ and they grew as normal plants. 


\section{Statistical Analysis}

All the experiments were set up in completely randomized design (CRD) with five replicates per treatment and with four explants per replicate (jar). Data were subjected to analysis of variance (ANOVA) and the statistical difference among the means was analyzed by Duncan's multiple range test (DMRT) Duncan (1995) at 5\% level of probability using statistical products and service solutions software for windows, version 17.0 (SPSS Inc., 2007).

\section{RESULTS AND DISCUSSION}

\section{Establishment Stage}

\section{Effect of Medium Strength, Explant Type and Cytokinin Type on Shoot Induction}

To study the effect of the interaction between MS media strength, explants type and cytokinins on shoot induction of Topas Brassica napus, $1.0 \mathrm{mgl}^{-1}$ of BA or Kin were added to the medium composition. After 4 weeks of culture, significant responses were recorded among the studied treatments.

The optimum shoot induction (98.66\%) with high number of shoot buds/ explant (3.36), shoot length $(2.69 \mathrm{~cm})$ and high leaves number/shoot (2.83) were observed by using shoot tip as explants on full MS medium supplemented with $1.0 \mathrm{mgl}^{-1} \mathrm{BA}$ within a period of 4 weeks (Table 1).

This result was followed by using axillary node as an explants on full MS with $1.0 \mathrm{mgl}^{-1}$ BA that gave $(86.33 \%$ shoot induction) with 3.03 shoot buds, $2.51 \mathrm{~cm}$ shoot length and 2.54 leaf per explant. Moreover, using $1.0 \mathrm{mgl}^{-1} \mathrm{Kin}$ found to be third best treatment recording $82.00 \%$ shoot induction, 2.04 shoots/explant, $1.96 \mathrm{~cm}$ shoot length and 1.82 leaves/explant.

It is clear that BA was the best cytokinin that induced the highest number of shoots compared with Kin or control treatments. This result is in agreement with
Zihang and Bhalla (2004); Chamandoosti et al., (2006); Moghaieb et al., (2006) and Thiyagarajan and Venkatachalam (2012) who mentioned that BA was more effective than other tested cytokinins for shoot initiation and development. The preference to use BA as cytokinin because its degradation is slow and it can be autoclaved without losing its activity. Furthermore, not only explant type (shoot tip or axillary node) but also MS medium strength (full or half MS) were significantly differed on shoot number, shoot length and leaves number. Data in (Table 1) indicate that all studied characteristics with shoot tip as an explant or in full MS were significantly higher than that with axillary node or in half MS medium.

\section{Multiplication Stage}

Effect of Cytokinin Type and Concentration on Multiple Shoot Formation

In vitro regenerated shoot buds from nodal explants were cultured on full strength MS medium with different concentrations $\left(0.0,0.1,0.5\right.$, and $\left.2.5 \mathrm{mgl}^{-1}\right)$ of BA or Kin individually.

Data shown in (Table 2) were revealed statistically significant differences between treatments at 5\% level. The optimum shoot growth with high number and without callus formation was observed using MS medium supplemented with $2.5 \mathrm{mgl}^{-1} \mathrm{BA}$ after 4 weeks from culture (Table 1 and Fig. 1) which shows 3.82 shoot buds, longest shoot $(3.03 \mathrm{~cm})$ and the highest number of leaves/explant (3.24). Then, using $0.5 \mathrm{mgl}^{-1}$ BA proved to be second best concentration recording 3.49 shoot buds and $2.87 \mathrm{~cm}$ shoot length.

Whereas, using $2.5 \mathrm{mgl}^{-1} \mathrm{Kin}$ found to be third best treatment recording 2.87 shoots/ explant and $2.44 \mathrm{~cm}$ shoot length with 2.41 leaves number/explant. The concentrations less than $2.5 \mathrm{mgl}^{-1} \mathrm{Kin}$ reduced shoot number, shoot length and leaves number of the two cytokinins tested in this investigation, BA was found to be most efficient for shoot multiplication than 
SINAI Journal of Applied Sciences (ISSN: 2314-6079) Vol. (5), Is. (1), Apr. 2016

Table (1): Effect of the interaction between media strength, explants type and cytokinins on shoot initiation of Brassica napus $L$. after 4 weeks of culture.

\begin{tabular}{|c|c|c|c|c|c|c|}
\hline $\begin{array}{l}\text { Media } \\
\text { strength }\end{array}$ & $\begin{array}{l}\text { Explant } \\
\text { s type }\end{array}$ & $\begin{array}{c}\text { PGRs } \\
\left(1 \mathrm{mgL}^{-1}\right)\end{array}$ & $\begin{array}{c}\text { Shoot } \\
\text { induction } \\
(\%)\end{array}$ & $\begin{array}{c}\text { Shoots } \\
\text { no./explant }\end{array}$ & $\begin{array}{c}\text { Shoot } \\
\text { length } \\
(\mathrm{cm})\end{array}$ & $\begin{array}{l}\text { No. of } \\
\text { leaves }\end{array}$ \\
\hline \multicolumn{7}{|c|}{4 weeks } \\
\hline \multirow{4}{*}{ Full MS } & \multirow{2}{*}{$\begin{array}{l}\text { Shoot } \\
\text { tip }\end{array}$} & BA & 98.66 & $3.36^{\mathrm{a}}$ & $2.69^{\mathrm{a}}$ & $2.83^{\mathrm{a}}$ \\
\hline & & Kin & 82.00 & $2.04^{\mathrm{c}}$ & $1.96^{\mathrm{c}}$ & $1.82^{\mathrm{c}}$ \\
\hline & \multirow{2}{*}{$\begin{array}{c}\text { Axillary } \\
\text { node }\end{array}$} & BA & 86.33 & $3.03^{b}$ & $2.51^{\mathrm{b}}$ & $2.54^{b}$ \\
\hline & & Kin & 79.00 & $1.87^{\mathrm{c}}$ & $1.64^{\mathrm{d}}$ & $1.72^{\mathrm{c}}$ \\
\hline \multirow{4}{*}{ Half MS } & \multirow{2}{*}{$\begin{array}{l}\text { Shoot } \\
\text { tip }\end{array}$} & $\mathbf{B A}$ & 73.33 & $1.04^{\mathrm{e}}$ & $0.89^{\mathrm{f}}$ & $0.43^{\mathrm{d}}$ \\
\hline & & Kin & 67.00 & $1.32^{\mathrm{d}}$ & $1.10^{\mathrm{e}}$ & $0.26^{\mathrm{f}}$ \\
\hline & \multirow{2}{*}{$\begin{array}{c}\text { Axillary } \\
\text { node }\end{array}$} & BA & 56.66 & $0.99^{\mathrm{e}}$ & $0.85^{\mathrm{f}}$ & $0.32^{\mathrm{e}}$ \\
\hline & & Kin & 49.33 & $1.02^{\mathrm{e}}$ & $1.10^{\mathrm{e}}$ & $0.20^{\mathrm{f}}$ \\
\hline
\end{tabular}

Means in each column followed by same letters are not significantly different according to Dunchan's multiple range test (DMRT) at $\alpha=0.05$.

Table (2): Influence of different concentrations of $\mathrm{BA}$ and Kin on morphogenic responses of single-shoot explants of Brassica napus L. established in vitro.

\begin{tabular}{cccccc}
\hline $\begin{array}{c}\text { Plant } \\
\text { growth } \\
\text { regulators }\end{array}$ & $\begin{array}{c}\text { Amount of } \\
\text { PGR } \\
(\mathbf{m g} / \mathbf{l})\end{array}$ & $\begin{array}{c}\text { Shoots } \\
\text { no./explant }\end{array}$ & $\begin{array}{c}\text { Average } \\
\text { shoot length } \\
(\mathbf{c m})\end{array}$ & Leaves no. & $\begin{array}{c}\text { Degree of } \\
\text { callus } \\
\text { formation* }\end{array}$ \\
\hline \multirow{2}{*}{ BA } & $\mathbf{0 . 0}$ & $1.12^{\mathrm{h}}$ & $1.04^{\mathrm{g}}$ & $1.03^{\mathrm{f}}$ & - \\
& $\mathbf{0 . 1}$ & $2.17^{\mathrm{e}}$ & $1.99^{\mathrm{d}}$ & $1.79^{\mathrm{d}}$ & - \\
& $\mathbf{0 . 5}$ & $3.49^{\mathrm{b}}$ & $2.87^{\mathrm{b}}$ & $2.17^{\mathrm{c}}$ & - \\
& $\mathbf{2 . 5}$ & $3.82^{\mathrm{a}}$ & $3.03^{\mathrm{a}}$ & $3.24^{\mathrm{a}}$ & - \\
\multirow{2}{*}{ Kin } & $\mathbf{0 . 1}$ & $1.65^{\mathrm{g}}$ & $1.47^{\mathrm{e}}$ & $1.61^{\mathrm{e}}$ & - \\
& $\mathbf{0 . 5}$ & $2.51^{\mathrm{d}}$ & $2.35^{\mathrm{cd}}$ & $2.02^{\mathrm{c}}$ & - \\
& $\mathbf{2 . 5}$ & $2.87^{\mathrm{c}}$ & $2.44^{\mathrm{c}}$ & $2.41^{\mathrm{b}}$ & + \\
\hline
\end{tabular}

*Callus formation (-, no callus; + , small callus less than $5 \mathrm{~mm}$ diameter; ++ , moderate callus 5-10 mm diameter; +++ , large callus more than $10 \mathrm{~mm}$ diameter). Data recorded after 4 weeks. 


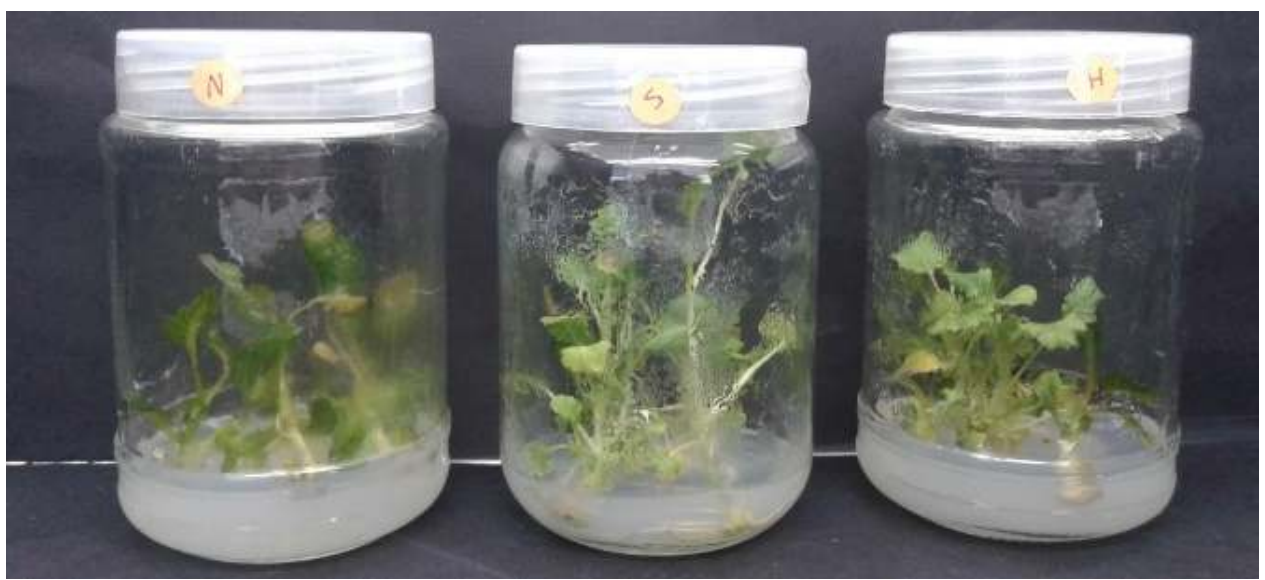

Fig. (1) : Morphogenic responses of Brassica napus using $2.5 \mathrm{mgl}^{-1} \mathrm{BA}$

Kin. This findings are in agreement with Zihang and Bhalla (2004); Chamandoosti et al. (2006); Moghaieb et al. (2006) and Thiyagarajan and Venkatachalam (2012). In addition, Similar findings have been reported with various plant species including Eclipta alba (Dhaka and Kothari, 2005), Quercus euboica (Kartsonas and Papafotiou, 2007), Ulmus parvifolia (Thakur and Karnosky, 2007), Stevia rebaudiana (Ahmad et al., 2011; Aman et al., 2013) and Sacostemma brevistigma (Thomas and Shankar, 2009). On the other hand, callus formation could not be established at all tested concentrations except the highest concentration $\left(2.5 \mathrm{mgl}^{-1}\right)$ of Kin, which produced small callus less than $5 \mathrm{~mm}$ diameter.

\section{Effect of Different Concentrations and Combination of PGRs on Multiple Shoot Formation}

At the same concentration $\left(1.0 \mathrm{mgl}^{-1}\right)$ of BA or Kin but here in combination with different concentrations of IBA or NAA $\left(0.1,0.5\right.$, or $\left.2.5 \mathrm{mgl}^{-1}\right)$ for multiple shoots bud proliferation, different response were observed as shown in Table 3. Among the tested combinations, a maximum initiation of healthy shoot buds (5.19) with higher shoot length $(3.47 \mathrm{~cm})$ and with higher leaves number/explant (3.12) were obtained within 4 weeks of culture using $1.0 \mathrm{mgl}^{-1}$ $\mathrm{BA}+0.5 \mathrm{mgl}^{-1}$ IBA combination (Fig. 2).
The obtained results are in harmony with that found by Thiyagarajan and Venkatachalam (2012), who noticed that $1.0 \mathrm{mgl}^{-1} \mathrm{BA}+0.5 \mathrm{mgl}^{-1}$ IBA combination was observed a very good shoot bud development with higher shoot length. The combination of $1.0 \mathrm{mgl}^{-1} \mathrm{BA}+2.5 \mathrm{mgl}^{-1}$ IBA was the second best treatment that gave (4.10) shoots/explant, $(2.88 \mathrm{~cm})$ shoot length and (2.59) leaves number/explant. Then, $\left(1.0 \mathrm{mgl}^{-1}\right) \mathrm{BA}+\left(2.5 \mathrm{mgl}^{-1}\right)$ NAA combination proved to be the third best treatment recording (3.19) shoots/explant and $(2.41 \mathrm{~cm})$ shoot length with $(2.16)$ leaves number/explant.

The obtained shoots here were higher in its number than in the previous experiment. However, addition of IBA along with BA has been reported to regenerate shoot buds from the nodal explants of Jatropha curcas Shrivastava and Banerjee (2008) and in Stevia rebaudiana (Atalaya et al., 2011; Aman et al., 2013) while addition of NAA along with $\mathrm{BA}$ has also been reported to regenerate shoot buds from the nodal explants of Brassica napus as mentioned by (Ghnaya et al., 2008; Burbulis et al., 2010). In this experiment, the best response of $1.0 \mathrm{mgl}^{-1} \mathrm{Kin}$ (3.19 shoots/ explant, 2.36 $\mathrm{cm}$ and 2.12 leaves/explant) was obtained in the presence of $0.5 \mathrm{mgl}^{-1}$ IBA. Moreover, presence of NAA in combination with Kin reduced shoot number, shoot length and leaves number. 
SINAI Journal of Applied Sciences (ISSN: 2314-6079) Vol. (5), Is. (1), Apr. 2016

Table (3): Influence of different concentrations and combination of PGRs on formation of multiple shoots Brassica napus $L$.

\begin{tabular}{ccccccc}
\hline \multicolumn{2}{c}{$\begin{array}{c}\text { Plant growth regulators } \\
\left.\text { ( } \text { mgL }^{-\mathbf{1}}\right)\end{array}$} & & Shoots no./explant & Shoot length (cm) & No. of leaves \\
\hline BA & Kin & IBA & NAA & & & \\
& - & $\mathbf{0 . 1}$ & - & $2.51^{\mathrm{e}}$ & $2.34^{\mathrm{cd}}$ & $2.10^{\mathrm{cd}}$ \\
& - & $\mathbf{0 . 5}$ & - & $5.19^{\mathrm{a}}$ & $3.47^{\mathrm{a}}$ & $3.12^{\mathrm{a}}$ \\
$\mathbf{1 . 0}$ & - & $\mathbf{2 . 5}$ & - & $4.10^{\mathrm{b}}$ & $2.88^{\mathrm{b}}$ & $2.59^{\mathrm{b}}$ \\
& - & - & $\mathbf{0 . 1}$ & $2.05^{\mathrm{f}}$ & $1.66^{\mathrm{e}}$ & $1.49^{\mathrm{e}}$ \\
& - & - & $\mathbf{0 . 5}$ & $2.85^{\mathrm{d}}$ & $1.84^{\mathrm{e}}$ & $1.65^{\mathrm{e}}$ \\
& - & - & $\mathbf{2 . 5}$ & $3.19^{\mathrm{c}}$ & $2.41^{\mathrm{c}}$ & $2.16^{\mathrm{c}}$ \\
- & & $\mathbf{0 . 1}$ & - & $2.51^{\mathrm{e}}$ & $1.87^{\mathrm{e}}$ & $1.68^{\mathrm{e}}$ \\
- & $\mathbf{0 . 5}$ & - & $3.19^{\mathrm{c}}$ & $2.36^{\mathrm{cd}}$ & $2.12^{\mathrm{cd}}$ \\
- & $\mathbf{1 . 0}$ & $\mathbf{2 . 5}$ & - & $2.73^{\mathrm{de}}$ & $2.15^{\mathrm{d}}$ & $1.93^{\mathrm{d}}$ \\
- & & - & $\mathbf{0 . 1}$ & $1.34^{\mathrm{h}}$ & $0.93^{\mathrm{h}}$ & $0.83^{\mathrm{h}}$ \\
- & & - & $\mathbf{0 . 5}$ & $1.76^{\mathrm{g}}$ & $1.19^{\mathrm{g}}$ & $1.07^{\mathrm{g}}$ \\
\hline
\end{tabular}

Means in each column followed by same letters are not significantly different according to Dunchan's multiple range test (DMRT) at $\alpha=0.05$. Data recorded after 4 weeks.

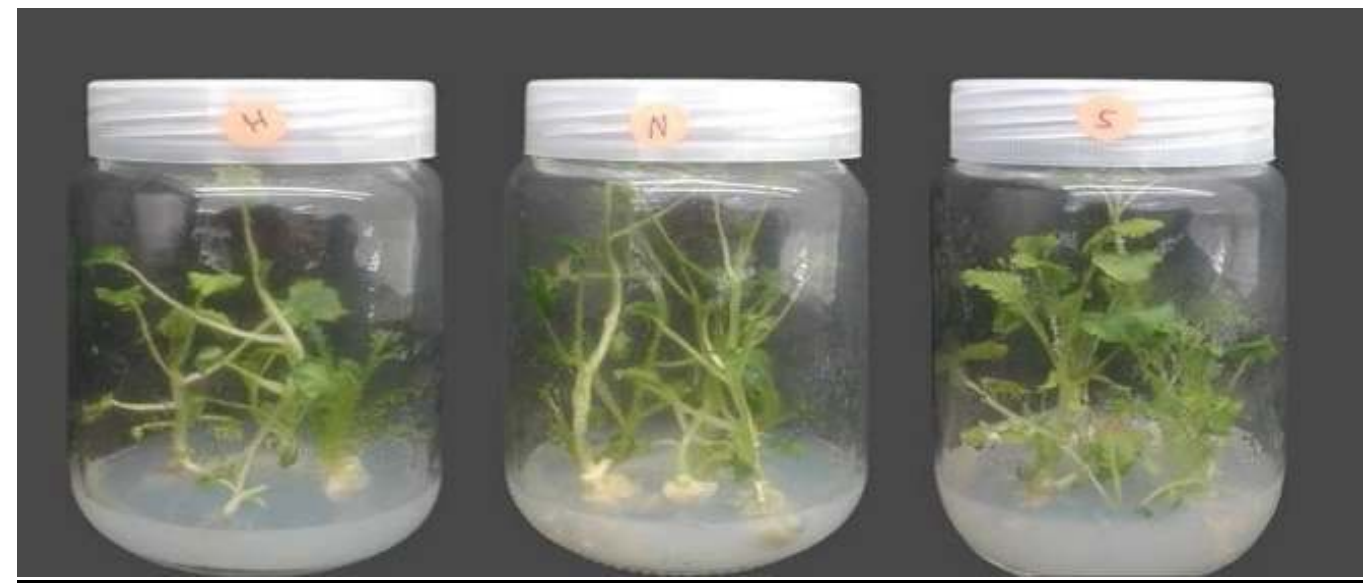

Fig. (2): Brassica napus multiple shoot formation using $\left(1.0 \mathrm{mgl}^{-1} \mathrm{BA}+0.5 \mathrm{mgl}^{-1} \mathrm{IBA}\right)$ 


\section{In vitro Rooting Stage}

\section{Effect of Auxin Type and Concentration on Adventitious Root Formation}

In present study, regenerated shoots (1-1.5 $\mathrm{cm}$ long) were cultured on half MS basal salt without vitamins medium containing different concentrations of IBA or NAA $(0.1,0.5$, or 2.5 $\mathrm{mgl}^{-1}$ ). IBA and NAA significantly increased roots number/shoot and root length (Table 4).

IBA and NAA increased root formation (\%), roots number/shoot and root length compared to the control treatment. The concentration of $2.5 \mathrm{mgl}^{-1} \mathrm{IBA}$ on half MS medium was found to be the optimum medium for root formation that gave a good root formation $(93.33 \%)$, highest roots number/shoot (3.54), and a highest root length $(2.70 \mathrm{~cm})$. Followed by $0.5 \mathrm{mgl}^{-1}$ IBA on half MS medium which proved to be second best treatment and gave a good root formation (86.66 \%), (2.97) roots number $/ \mathrm{shoot}$, and $(2.30 \mathrm{~cm})$ root length.

Then $2.5 \mathrm{mgl}^{-1} \mathrm{NAA}$ on half MS medium was found to be third best treatment that gave $(84.00 \%)$ root formation, (2.64) roots number/shoot, and $(1.99 \mathrm{~cm})$ root length. The findings that reported for Citrus auriantifolia Swingle by Bhatt and Tomar (2010) and for Jatropha curcas by Toppo et al. (2012) indicate that low concentrations of IBA $\left(0.5 \mathrm{mgl}^{-1}\right)$ proved to be more efficient for root formation whilst Zihang and Bhalla (2004) and Burbulis et al.,
(2010) stated that proliferated shoots were rooted with NAA. On the other hand, callus formation could not be established at all tested concentrations except the highest concentration $\left(2.5 \mathrm{mgl}^{-1}\right)$ of IBA or NAA, which produced small callus less than $5 \mathrm{~mm}$ diameter.

Effect of Different Combinations of Auxins on Adventitious Root Formation

As shown from results in Table 5, 0.5 $\mathrm{mgl}^{-1}$ IBA in combination with three concentrations $\left(0.1,0.5\right.$, or $\left.2.5 \mathrm{mgl}^{-1}\right)$ of IAA, NAA or 2,4-D were used to study its influence on adventitious root formation. The maximum number of roots (3.72) with longest roots $(4.17 \mathrm{~cm})$ were obtained with $0.5 \mathrm{mgl}^{-1} \mathrm{IBA}+0.1 \mathrm{mgl}^{-1}$ IAA on half MS basal salts (Fig.3). However, the combination of $0.5 \mathrm{mgl}^{-1} \mathrm{IBA}+0.1 \mathrm{mgl}^{-1}$ NAA recorded the second best root number (3.32) without significant differences with 0.5 $\mathrm{mgl}^{-1} \mathrm{IBA}+0.1 \mathrm{mgl}^{-1}$ 2,4-D that gave (3.27 roots/shoot).

Generally, increasing the concentration of IAA, NAA and 2,4-D from 0.1 to $2.5 \mathrm{mgl}^{-1}$ in the presence of $0.5 \mathrm{mgl}^{-1}$ IBA decreased roots number/shoot and root length. Thus, there was no callus formation on half MS medium with the lowest concentration (0.1 $\mathrm{mgl}^{-1}$ ) of IAA, NAA or 2,4-D in the presence of $0.5 \mathrm{mgl}^{-1}$ IBA. But much callus growth was formed with the other combinations.

Table (4): Influence of Auxins concentrations on adventitious root initiation of Brassica napus plant (half MS basal salt medium without vitamins was used).

\begin{tabular}{cccccc}
\hline \multirow{2}{*}{$\begin{array}{c}\text { Amount of Auxin } \\
\left(\mathbf{m g L}^{-1}\right)\end{array}$} & \multicolumn{5}{c}{ Average growth } \\
\cline { 3 - 6 } & $\begin{array}{c}\text { Root } \\
\text { formation/shoot (\%) }\end{array}$ & $\begin{array}{c}\text { Roots no. } \\
\text { /shoot }\end{array}$ & $\begin{array}{c}\text { Root length } \\
(\mathbf{c m})\end{array}$ & $\begin{array}{c}\text { Callus } \\
\text { formation }\end{array}$ \\
\hline IBA & $\mathbf{N A A}$ & & & & \\
$\mathbf{0 . 0}$ & $\mathbf{0 . 0}$ & 00.00 & $0.00^{\mathrm{g}}$ & $0.00^{\mathrm{g}}$ & - \\
$\mathbf{0 . 1}$ & - & 76.66 & $1.74^{\mathrm{e}}$ & $1.38^{\mathrm{e}}$ & - \\
$\mathbf{0 . 5}$ & - & 86.66 & $2.97^{\mathrm{b}}$ & $2.30^{\mathrm{b}}$ & - \\
$\mathbf{2 . 5}$ & - & 93.33 & $3.54^{\mathrm{a}}$ & $2.70^{\mathrm{a}}$ & + \\
- & $\mathbf{0 . 1}$ & 63.33 & $1.50^{\mathrm{f}}$ & $1.04^{\mathrm{f}}$ & - \\
- & $\mathbf{0 . 5}$ & 80.33 & $2.25^{\mathrm{d}}$ & $1.67^{\mathrm{d}}$ & - \\
- & $\mathbf{2 . 5}$ & 84.00 & $2.64^{\mathrm{c}}$ & $1.99^{\mathrm{c}}$ & + \\
\hline
\end{tabular}

Means in each column followed by same letters are not significantly different according to Dunchan's multiple range test (DMRT) at $\alpha=0.05$. Data recorded after 4 weeks. 
SINAI Journal of Applied Sciences (ISSN: 2314-6079) Vol. (5), Is. (1), Apr. 2016

Table (5): Effects of different concentration and combination of auxins on adventitious root formation.

\begin{tabular}{|c|c|c|c|c|c|}
\hline \multicolumn{2}{|c|}{ Auxins } & \multirow{2}{*}{$\frac{\begin{array}{c}\text { Amount } \\
\left(\mathrm{mgL}^{-1}\right)\end{array}}{0.1}$} & \multirow{2}{*}{$\begin{array}{c}\begin{array}{c}\text { Roots } \\
\text { no./shoot }\end{array} \\
3.72^{\mathrm{a}}\end{array}$} & \multirow{2}{*}{$\begin{array}{c}\begin{array}{c}\text { Root length } \\
\text { (cm) }\end{array} \\
4.17^{\mathrm{a}}\end{array}$} & \multirow{2}{*}{$\begin{array}{c}\begin{array}{c}\text { Degree of callus } \\
\text { formation }\end{array} \\
-\end{array}$} \\
\hline & & & & & \\
\hline \multirow{8}{*}{ IBA $0.5+$} & IAA & 0.5 & $2.77^{\mathrm{c}}$ & $3.18^{\mathrm{c}}$ & + \\
\hline & & 2.5 & $1.96^{\mathrm{e}}$ & $2.30^{\mathrm{e}}$ & ++ \\
\hline & & 0.1 & $3.32^{\mathrm{b}}$ & $3.82^{\mathrm{b}}$ & - \\
\hline & NAA & 0.5 & $2.70^{\mathrm{c}}$ & $2.76^{\mathrm{d}}$ & + \\
\hline & & 2.5 & $1.38^{\mathrm{f}}$ & $1.59^{\mathrm{f}}$ & ++ \\
\hline & & 0.1 & $3.27^{\mathrm{b}}$ & $3.24^{\mathrm{c}}$ & - \\
\hline & 2,4-D & 0.5 & $2.65^{\mathrm{c}}$ & $2.76^{\mathrm{d}}$ & + \\
\hline & & 2.5 & $2.33^{d}$ & $2.20^{\mathrm{e}}$ & ++ \\
\hline
\end{tabular}

Means in each column followed by same letters are not significantly different according to Dunchan's multiple range test (DMRT) at $\alpha=0.05$. Data recorded after 4 weeks.

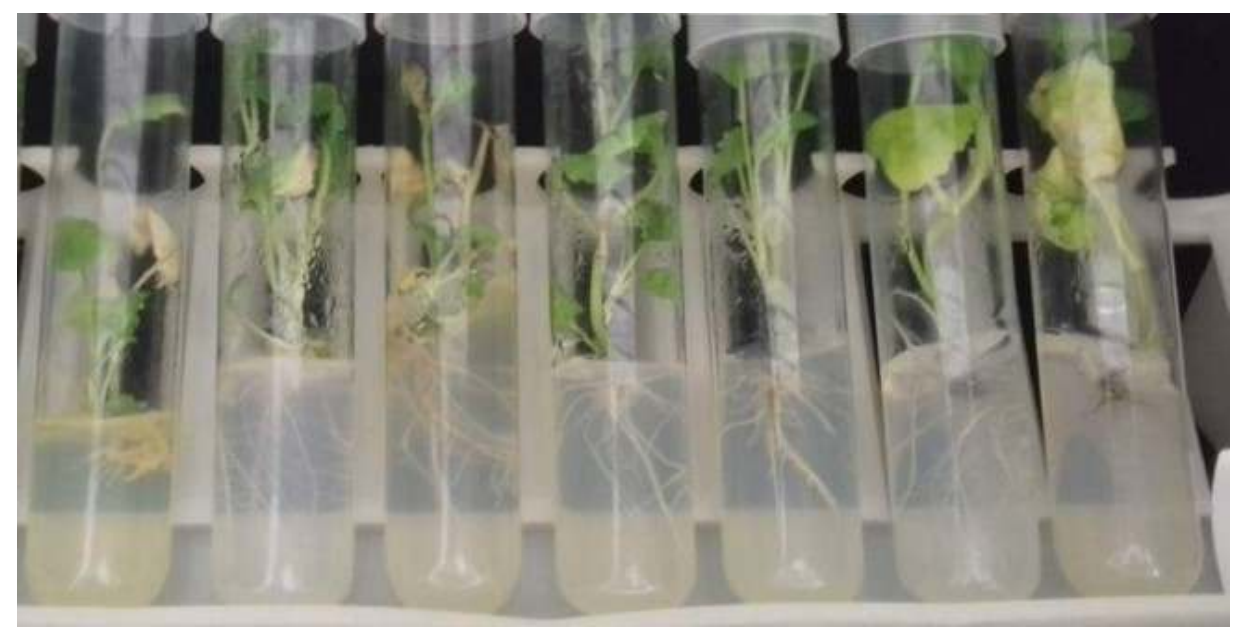

Fig. (3): In vitro root formation of Brassica napus using $\left(0.5 \mathrm{mgl}^{-1} \mathrm{IBA}+0.1 \mathrm{mgl}^{-1} \mathrm{IAA}\right)$ 


\section{REFERENCES}

Ahmad, N., H. Fazal, R. Zamir, S.A. Khalil and B.H. Abbasi (2011). Callogenesis and shoot organogenesis from flowers of Stevia rebaudiana (Bert.). Sugar Tech. 13: 174-177.

Aman, N., F. Hadi, S.A. Khalil, R. Zamir and N. Ahmad (2013). Efficient regeneration for enhanced steviol glycosides production in Stevia rebaudiana (Bertoni). Comptes Rendus Biologies 336: 486-492.

Al-Naggar, A. M. M., M. M. Saker, R. Shabana, S. A. Ghanem, A. H. Reda and S. A. Eid (2008). In vitro selection and molecular characterization of salt tolerant canola plantlets. Arab journal of biotechnology 11(2): 207-218.

Atalaya, E., S. Erisen, M. Yorgancilar, M. Tanur (2011). Micropropagation of Stevia rebaudiana Bertoni. Abstracts/Current Opinion in Biotechnology. 22, 135.

Bennett, R.A., M.R. Thiagarajah, J.R. King and M.H. Rahman (2008). Interspecific cross of Brassica oleracea var. Alboglabra and B. napus: effects of growth condition and silique age on the efficiency of hybrid production, and inheritance of erucic acid in the selfpollinated backcross generation. Euphytica 164: 593-601.

Bhatt, B., Y. Tomar (2010). Effects of IBA on rooting performance of Citrus auriantifolia Swingle (Kagzilime) in different growing conditions. Nat. Sci. $8: 8-11$

Borjian, L. and H. Arak (2013). A study on the effect of different concentration of plant hormones (BAP, NAA, 2, 4-D, and Kinetin) on callus induction in Brassica napus. International Research Journal of Applied and Basic Sciences 5 (4): 519-521.
Burbulis, N., A. Blinstrubienè and R. Kuprienė (2010). Genotypic and growth regulator effects on shoot regeneration from hypocotyl and stem segment explants of spring rapeseed (Brassica napus L.). Journal of Food, Agriculture \& Environment 8 (2): 634-637.

Cao, Y., Y. Wang and W. Liu (2010). Maturation of microspores of Brassica napus L. in vitro. Acta Bot. Boreal. Occident. Sin. 30: 399-404.

Cardoza, V. and C. N. Stewart (2004). Brassica biotechnology: progress in cellular and molecular biology. In vitro Cellular \& Developmental Biol. Plant 40(6): 542-551.

Chamandoosti, F., A. Majd and S. Mehrabian (2006). In vitro plant regeneration from callus of cotyledons in canola (Brassica napus L.). Pakistan Journal of Biological Sciences 9 (2): 302-306.

Cheng, L.H., J.M. Yin, N. Lin, Q.Y. Zhou, Z.L. Tang and J.N. Li (2005). Preliminary research on in vitro culture of cotyledon from yellow-seeded Brassica napus L. Chinese Agric. Sci. Bull. 21: 31-33.

Dhaka, N. and S.L. Kothari (2005) Micropropagation of Eclipta alba (L.) Hassk. An important medicinal plant. In vitro Cell. Dev. Biol. Plant 41: 770-774.

Duncan, B.D. (1995). Multiple ranges and multiple F test. Biometrics 11: 1-42.

Eapen, S. and L. Georg (1997). Plant regeneration from peduncle segments of oil seed Brassica species: influence of silver nitrate and silver thiosulfate. Plant Cell Tiss. Organ Cult. 51: 229-232.

El-Howeity, M.A. and M.M. Asfour (2012). Response of some varieties of canola plant (Brassica napus L.) cultivated in a newly reclaimed desert to plant growth promoting rhizobacteria and mineral nitrogen fertilizer. Ann. of Agric. Sci. 57(2): 129-136. 
Ghnaya, A. B., G. Charles and M. Branchard (2008). Rapid shoot regeneration from thin cell layer explants excised from petioles and hypocotyls in four cultivars of Brassica napus L. Plant Cell Tissue and Organ Culture 92: 25-30.

He, Y., G.L. Wan, G.X. Tang, L. Xu and W.J. Zhou (2006). Studies on the enhancement of plant regeneration from hypocotyl explants of Brassica napus. J. Zhejiang University 32: 46-50.

Huang, X.Q. (2006). Advances of regeneration in vitro system of cotyledon and hypocotyl and their genetic transform in rape. Southwest China J. Agric. Sci. 19: 152-158.

Hussain, S., A. Rasheed, M. Latif, T. Mahmood and S.M.S. Naqvi (2014). Canola (Brassica napus L.) regeneration and transformation via hypocotyl and hypocotyl derived calli. Sarhad Journal of Agriculture 30(2): 165-172.

Ismail, R. M. (2012). Establishment of regeneration and transformation of Brassica napus. Egyptian Journal of Genetics and Cytology 41: 163-180.

Kartsonas, E. and M. Papafotiou (2007). Mother plant age and seasonal influence on in vitro propagation of Quercus euboica Pap., an endemic, rare and endangered oak species of Greece. Plant Cell Tiss. Org. Cult. 90: 111-116.

Liu, X.Q., Y. Shen, X.N. Cai, H.M. Pu and Q.G. Dai (2008). Research on the plant regeneration from hypocotyl of Brassica napus L. J. Anhui Agric. Sci. 36: 1354713548.

Maheshwari, P., G. Selvaraj and I. Kovalchuk (2011). Optimization of Brassica napus (canola) explant regeneration for genetic transformation. New Biotechnology 29 (1): 144-155.

Moghaieb, R.E.A., M.A. El-Awady, R.G. El Mergawy, S.S. Youssef and A.M.
El-Sharkawy (2006). A reproducible protocol for regeneration and transformation in canola (Brassica napus L.). African Journal of Biotechnology 5 (2): 143-148.

Murashige, T. and F. Skoog (1962). A revised medium for rapid growth and bioassays with tobacco tissue. Physiol. Plant. 15: 473-497.

Shi, S.W., J.S. Wu and Q.S. Niu (2007). In vitro microspores mutagensis in Brassica napus-response of microspore embryogenesis to UV radiation. J. Nucl. Agric. Sci. 21: 17-19.

Shrivastava, S., M. Banerjee (2008). In vitro clonal propagation of physic nut (J. curcas L.): Influence of additives. Inter. J. of Integr. Biol. 3:73-79.

SPSS Inc. (2007). SPSS for Windows. Release 16.0. SPSS Inc., Chicago, IL.

Thakur, R.C. and D.F. Karnosky (2007). Micropropagation and germplasm conservation of central park splendor Chinese elm trees. Plant Cell Rep. 26: 1171-1177.

Thiyagarajan, M. and P. Venkatachalam (2012). Large-scale in vitro propagation of Stevia rebaudiana (Bert.) for commercial application: pharmaceutically important and antidiabetic medicinal herb. Ind. Crops and Prod. 37: 111-117.

Thomas, T.D. and S. Shankar (2009). Multiple shoot induction and callus regeneration in Sarcostemma brevistigma wight and Arnott, a rare medicinal plant. Plant Biotech. Rep. 3: 67-74.

Toppo, D.D., G. Singh, D.K. Purshottam, P. Misra (2012). Improved in vitro rooting and acclimatization of Jatropha curcas plantlets. Biomass and Bioenergy J. 44:42-46.

Zihang, Y. and P. L Bhalla (2004). In vitro shoot regeneration from commercial cultivars of Australian canola (Brassica napus L.). Australian Journal of Agricultural Research 55: 753-756. 


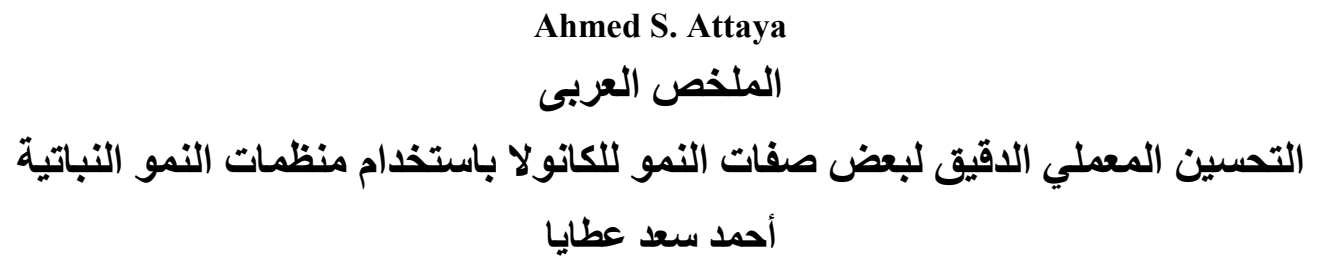

الملخص العربى

التحسين المعملي الاقيق لبعض صفات النمو للكانولا باستخدام منظمات النمو النباتية

أحمد سعد عطايا

قسم الإنتاج النباتي، كلية العلوم الزراعية البيئية بالعريش، جامعة قناة السويس، مصر

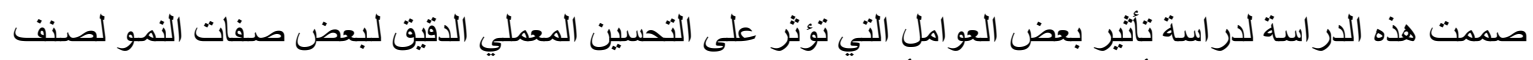

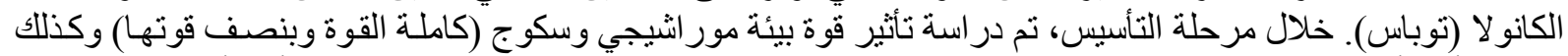

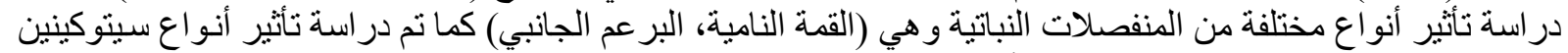

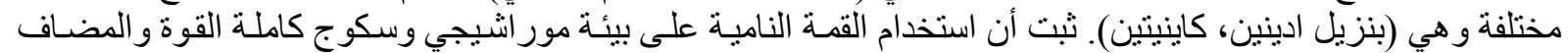

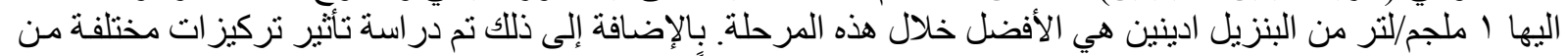

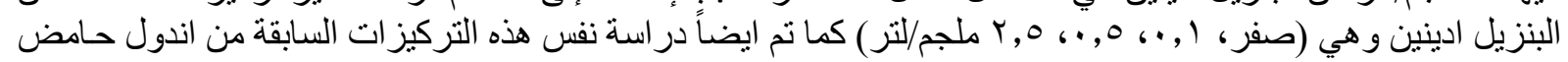

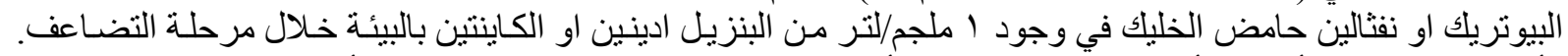

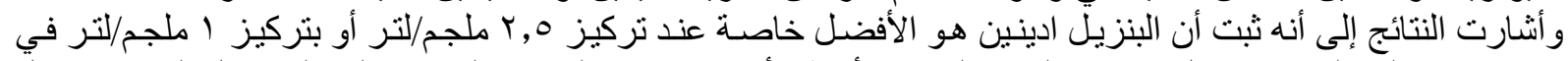

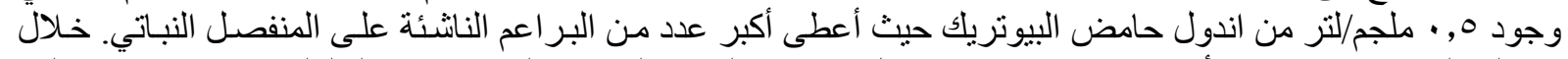

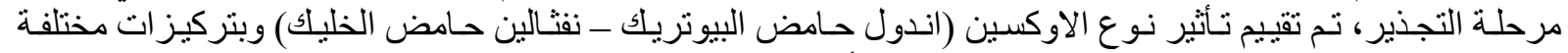

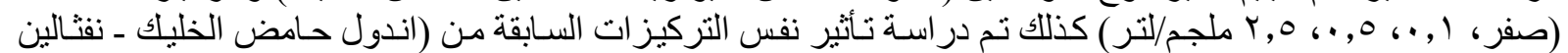

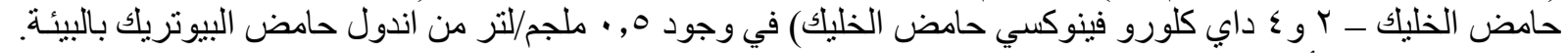

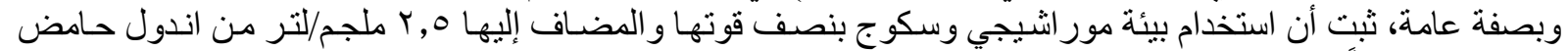

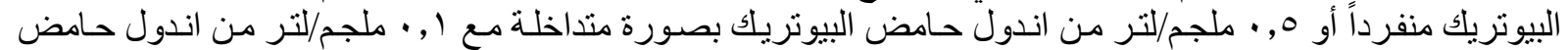

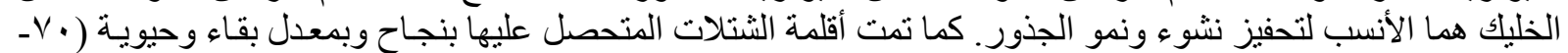

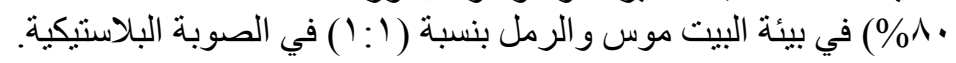

الكلمات الإسترشادية: الكانو لا، إنماء وتضاعف البر اعم، منظمات النمو النباتية، بيئة مور اشيجي وسكوج، التجذير المعلي. 